Research

\title{
Many Eyes on Nature: Diverse Perspectives in the Cape Horn Biosphere Reserve and Their Relevance for Conservation
}

\author{
$\underline{\text { Uta Berghoefer }}^{1}, \underline{\text { Ricardo Rozzi }}^{2,3}$, and $\underline{\text { Kurt Jax }}^{1}$
}

\begin{abstract}
Relationships between humans and nature take multiple forms. This is a fundamental issue in conservation but one that is often neglected, leading to poor conservation outcomes. It is thus imperative that we come to understand better the complex relationships between humans and nature. To do so, we need to examine "nature" and the often assumed dichotomy between humans and nature. We conducted a qualitative social research inquiry to explore the societal relationships with nature in the Cape Horn Biosphere Reserve in Chile. From the results, we developed a framework that illustrates how different "natures" are created in the three-way relationship among the individual, society, and the physical world. We further discuss the implications of the co-existence of various "natures" in one place. Their explicit consideration bears important potential for improving conservation practice. The framework can then serve as a heuristic tool for uncovering and addressing challenges in other conservation contexts.
\end{abstract}

Key Words: biodiversity; biosphere reserve; Chile; conflicts; conservation; local ecological knowledge; participation; protected areas; valuation

\section{INTRODUCTION}

Relationships between humans and nature take multiple forms. This is a fundamental issue in conservation but one that is often neglected, leading to poor conservation outcomes. It is thus imperative that we come to a better understanding of the complex relationships between humans and nature. To do so, we need to examine "nature" and the often assumed dichotomy between humans and nature. This requires extending the notion of human needs beyond purely economic ones and also considering how nature is created and shaped by political contexts, cultural values, personal ties, and other determinants.

Nature conservation has always vacillated between preservationist approaches that exclude humans from nature, e.g., the wilderness debate (Oehlschlaeger 1991, Cronon 1995, Callicott and Nelson 1998, Sarkar 1999, Nelson and Callicott 2008), and approaches that incorporate human needs and values in an attempt to reconcile them with the protection of biodiversity and ecosystems (Posey 1999, Infield 2001, Maffi 2001, WCPA 2000, 2004). The evolution of the IUCN Protected
Area Management Categories reflects this debate at the international level, and the question of whether the sustainable use of natural resources is valid as an objective for a protected area remains a highly contested one (Terborgh 2004, Locke and Dearden 2005, IUCN 2008). Although human activities in protected areas are referred to in categories $\mathrm{V}$ and VI, the implication is one of incremental degrees of human intervention, such that untouched nature is still regarded as the "better" or the "real" nature. The description of category $\mathrm{V}$ found in the guidelines for applying the categories states that "[b]eing a relatively flexible model, category $\mathrm{V}$ may sometimes offer conservation options where more strictly protected areas are not feasible" (IUCN 2008:21). This "nature first" approach is rooted in the national park concept (Runte 1997) and has guided much ecological research (Shelford 1943, Tjossem 1994, Arcese and Sinclair 1997, Sinclair 1998).

At the same time, the recommendations that emerged from the Fifth World Parks Congress 2003 in Durban (IUCN 2003) strongly urge that conservation should not lead to further social injustices and that the establishment of a protected 
area should not be allowed to exacerbate poverty, as has been the case in the past (Cernea and SchmidtSoltau 2006). The displacement of local people from protected areas and the relationship between conservation and poverty reduction are among the most controversial and contested issues currently being debated (Adams et al. 2004, Brockington and Igoe 2006, West et al. 2006, Adams and Hutton 2007, Fisher and Christopher 2007, Dowie 2009, Agrawal and Redford 2009). Furthermore, considering the fact that international conservation organizations have become increasingly powerful in influencing conservation policy in protected areas (Chapin 2004, Zimmerer 2006), it is unclear to what extent one can claim that "the objectives of management of land, water and living resources are a matter of societal choice," as expressed succinctly in the Malawi Principles describing the Ecosystem Approach of the Convention on Biological Diversity (UNEP/CBD 2000:104).

The intensity of debate surrounding the relationship of conservation to human rights and development needs (Sanderson and Redford 2003, 2004, 2006, Adams et al. 2004, Brockington and Schmidt-Soltau 2004, Brockington et al. 2006, Redford et al. 2006) demonstrates that attempts to reconcile conservation and human development have by no means proved to be an unalloyed success. When it comes to the actual practice of managing a specific area, conflicts often arise (Agrawal and Gibson 1999, Thompson 2002, Campbell and Vainio-Mattila 2003, Zimmerer 2006). We believe that community-based management and conservation of ecosystems and the multiple services they provide (Berkes 2004, Borrini-Feyerabend et al. 2004, WCPA 2004) can be further strengthened by considering more closely diverse societal relationships with nature.

Based on work conducted in the recently designated Cape Horn Biosphere Reserve in southern Chile, we explore just how diversely nature is configured by different people, i.e., how they think about, relate to, and inhabit it. In this article, we build on and extend the German concept of gesellschaftliche Naturverhältnisse, which different authors have translated into English as "societal relation to nature" (Becker and Jahn 2005, 2006) and "societal relationship with nature" (Görg 2004). We first present the concept of societal relationships with nature and introduce our study site and the methods used. We describe the various relationships with nature that we encountered. Using qualitative social research based on grounded theory, we explore the making of different natures in the context of the Cape Horn Biosphere Reserve. We develop a framework that translates the concept of societal relationships with nature into a heuristic tool suited to carrying out empirical work in conservation settings, and discuss some of the implications for conservation practice entailed in our understanding of natures. Despite any grammatical incorrectness, we use the term "natures" as an analytic term without quotation marks.

\section{Beyond dichotomies: societal relationships with nature}

It is generally considered common sense that nature comprises everything that lives or organizes itself beyond the realm of human influence, and that it comes closest to being true or real when humans have as little influence on it as possible. We believe that this simplistic understanding of nature as existing in separation from human beings lies at the root of many conservation problems. Nature is not just a thing that is somewhere "out there," to be either consumed or protected. Instead, it is constituted through a three-way relationship between the individual, society, and the physical world. We understand nature itself not as a given, causal, objective entity, but as a sphere whose boundaries are dynamic and socially constructed (Görg 2003, 2004, 2010, Becker and Jahn 2005, 2006). We see these boundaries not as fixed but as subject to historical change. The way humans interact with nature shapes their understanding of it, whereas the ways in which nature is represented in turn frame and inspire the ways in which people behave toward and inhabit it. Both elements, society and nature, are what they are only through their relationship to each other (Görg 2010).

There is a growing number of scholars from various fields, including sociology, geography, science and technology studies, and anthropology, who have likewise developed approaches to rethinking the relationships between humans and nature (Haraway 1991, 2008, Gómez-Pompa and Kaus 1992, Greider and Garkovich 1994, Cronon 1995, Braun and Castree 1998, Escobar 1998, Ingold 2000, Castree and Braun 2001, Whatmore 2002, Latour 2004, Thrift 2005, Hinchliffe 2007, 2008). Some focus on "social nature" (Castree and Braun 2001) and analyze the ways in which nature is socialized and why it matters (Cronon 1995, Braun and Castree 1998, Castree and Braun 2001). Drawing on work 
by science studies scholars such as Latour (1993, 2004) and Haraway (1991, 2008), other authors (Escobar 1998, Whatmore 2002, Hinchliffe 2007, 2008) go further, shifting the focus from a concern for nature itself to a particular way of considering associations of humans and nonhumans. Actor network theory, for example, posits the existence of hybrids or "quasi-objects," arguing that actors are at once social and natural, or "socio-material imbroglios" (Whatmore 2002:4, see also Latour 1993), and analyzing how these actors relate to each other in networks.

The concept of societal relationships with nature (Görg 2003, 2004, 2010, Becker and Jahn 2005, 2006) has been developed in environmental sociology as one approach that seeks to analyze how nature and society are related to each other. Although this concept does not discard the more general meanings assigned to nature and society, at the empirical level it declines to treat them as nondifferentiated entities that relate to each other as separate wholes; instead, it sees them in terms of differentiated social and natural elements that are selectively and dynamically linked (Becker and Jahn 2005). This understanding serves as a point of departure for our empirical research.

The claim that nature and biodiversity are not given entities but are socially constructed has shocked many conservationists and natural scientists (Crist 2004), who fear that "certain contemporary forms of intellectual and social relativism can be just as destructive to nature as bulldozers and chain saws" (Soulé and Lease 1995:xvi). The term "social construction" is a highly contested one (for a more detailed discussion, see, e.g., Hacking 1999, Demeritt 2002). However, understanding nature as socially constructed does not mean that we can neglect the material conditions of a physical world; on the contrary, the physical world may well behave in a way that disrupts or destabilizes the construction process. We emphasize that both social construction and material conditions play a role in creating natures.

The specific task that arises out of these theoretical considerations is that of analyzing "practices of differentiation" (Becker and Jahn 2006). There are several issues here that require closer definition (Thompson 2002). For example, which nature is worth conserving? From what is nature to be protected? By whom is it to be saved? How is it to be saved? These questions pave the way to understanding the making of nature as a political act as well: Ideas are formulated, shared, and applied in ways that are political, because the negotiation of ideas takes place in a context of power struggles (Escobar 1998, Adams and Hutton 2007).

In summary, the concept of societal relationships with nature asserts that (1) nature is not a given but is rather a result of the relations that exist among the individual, society, and the physical world; (2) the making of nature is a political and historical process; and (3) multiple alternative relationships exist whose outcomes we call "natures." Against this background, we now examine the different competing and contested natures that co-exist in the Cape Horn Biosphere Reserve.

\section{Study site: the Cape Horn Biosphere Reserve}

In 2005, after a five-year process, a new UNESCO Biosphere Reserve was established in the Cape Horn region in southern Chile. This is one of the largest such reserves in Latin America, comprising almost 5 million ha of land and seascape (Rozzi et al. 2006a) and a human population of around 2300 inhabitants, most of whom live in the remote town of Puerto Williams on Navarino Island (Fig. 1).

The social map of the Cape Horn Biosphere Reserve is complex (Berghöfer 2002) and includes (1) the indigenous Yaghan community; (2) permanent residents, some with European ties; (3) rotating Navy personnel with their families; and (4) public employees, often temporary residents, working for public authorities. One important actor in conservation and a leading one in the biosphere reserve initiative is the Omora Foundation, a Chilean NGO set up by Chilean and foreign scientists in 2000 .

Puerto Williams was established in 1953 as a military base in response to border conflicts with Argentina. Recently, the privatization and commercialization of previously subsidized public services have raised the cost of living dramatically in this remote area with limited employment opportunities. The region's vast expanses of intact habitats are now facing a number of challenges from (1) the opening up of fishing grounds and areas for salmon farming that had previously been restricted by the Navy, (2) new navigation routes and coastal concessions for tourism, and (3) increased access via air and land routes. The biosphere reserve was 
Fig. 1. The Cape Horn Region.

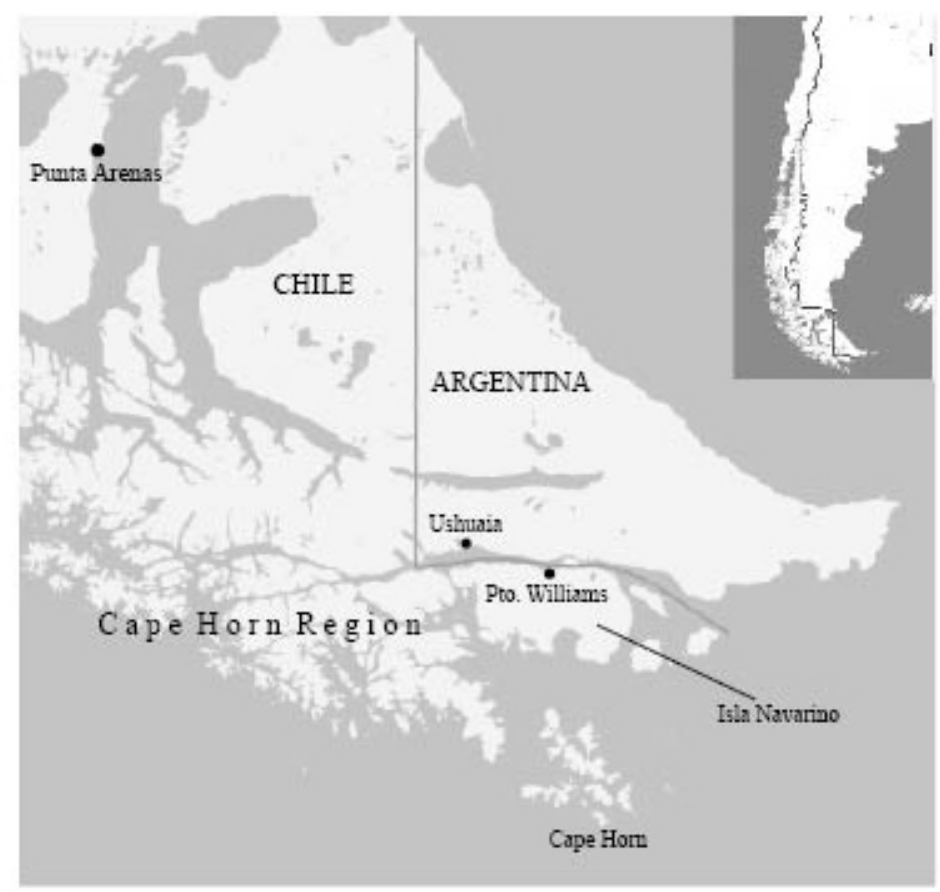

set up with the aim of providing a framework for sustainably protecting and developing the region.

\section{METHODS}

We used a qualitative approach in our analysis of societal relationships with nature. Research methods included extended participant observation, qualitative semistructured interviews, and focus groups. Our analysis is based on grounded theory (Strauss and Corbin 1998, Charmaz 2006), a methodological approach helpful for elaborating empirically based theories. Our data collection, empirical analysis, and theoretical reflections were combined in an iterative process.

Between August 2003 and August 2006 we conducted 68 interviews and four focus group discussions with inhabitants of Puerto Williams belonging to different sociocultural groups (Table 1). Participant observation conducted since 1998 complemented these methods.

Individuals from each sociocultural group were interviewed using qualitative semistructured interviews conducted in Spanish. The general research questions were: How do people perceive, value, and live with nature and biodiversity in the Cape Horn region? Can people's relationships with nature be specified according to particular categories, and, if so, which ones?

The first 23 interviews were analyzed using wordby-word and line-by-line coding (open coding). The codes generated in the first phase of analysis guided the interviews that followed. The codes that emerged from second- and third-round interviews were subsequently grouped into the three overarching categories described in the following section: knowledgescape, interactions, and identity. Data analysis was conducted on the basis of the Spanish interviews and transcripts. The quotations were translated by the authors for the purpose of this article. More details on data collection and analysis are given in Appendix 1. Appendix 2 contains key quotations from the interviews. In Appendix 3 we present our interview guidelines, and Appendix 4 gives an example of a word-by-word analysis. 
Table 1. Respondents according to sociocultural groups and year of interview.

\begin{tabular}{lcccccc}
\hline \hline Sociocultural group & Total & Women & Men & $\begin{array}{c}\text { Interviewed in } \\
2004\end{array}$ & Interviewed in 2005 & Interviewed in 2006 \\
\hline Public employees & 15 & 6 & 9 & 9 & 7 (1 also 2004) & $\ldots$ \\
Residents & 25 & 9 & 16 & 13 & 5 & $9(2$ also 2005) \\
Yaghan community & 12 & 5 & 7 & 8 & $4(1$ also 2004) & 2 (1 also 2004) \\
Navy & 17 & 7 & 10 & 6 & 11 & $\ldots$ \\
Total & 69 & 27 & 42 & 36 & 27 & 11 \\
\hline
\end{tabular}

\section{RESULTS}

\section{The framework: societal relationships and the making of natures}

Based on the interview analysis described above, we identified three main categories, each containing essential components of the relationships between individuals and nature in the Cape Horn Region. We named these "knowledgescape," "interactions," and "identity". Figure 2 shows how the categories are integrated into a framework encompassing the relationships among individuals, elements of society, and elements of the physical world. For each category several subcategories and dimensions have been identified that characterize different relationships with nature in the Cape Horn Region.

\section{Knowledgescape}

Knowledgescape, a term borrowed from Matthiesen (2005), was assigned to the category comprising elements of knowledge along with knowledge transfer and background. The subcategory "elements of knowledge" denotes what is known, whereas knowledge transfer and background refer to how the process of knowledge acquisition takes or took place and where this knowledge originates from. Knowledge transfer ranges in spatial terms from local to global channels and typologically from practical, experimental knowledge to mediated, cognitive knowledge. These dimensions are understood not as mutually exclusive opposites but as interpenetrating elements on a sliding scale. We thus recognize not only that knowledge encompasses facts or information but also that, as the interviews showed, it has a particular history and function. Describing different processes of knowledge transfer helps to overcome notional dichotomies between knowing and not knowing as well as between local and scientific or global knowledge (Agrawal 1995, Görg 2003, Pedynowski 2003, Brosius 2004).

With regard to the elements of knowledge, we analyzed which animals, birds, plants, landscapes, and places were named. Although most of the animal species mentioned by the interviewees were mammals, their answers also included a wide range of species, from endemic to exotic species and from wild to domestic ones. The animals named most frequently across all social groups were horses, cows, and dogs. Knowledge about plants differed more markedly. Whereas navy people, more recent settlers, and employees working for the public authorities referred generally to ornamental plants and flowers, permanent residents and interviewees from the Yaghan community named edible plants from the region or referred to different uses of the plants. The inhabitants of Puerto Williams also proved to have varying kinds of spatial knowledge. Very few interviewees mentioned areas not directly accessible by car or boat.

With regard to knowledge transfer and background, we identified several ways in which knowledge acquisition takes place, ranging from personal experience and learning from family members to school education and science lessons. Personal experience through direct interaction with the local 
Fig. 2. Societal relationships and the making of natures.

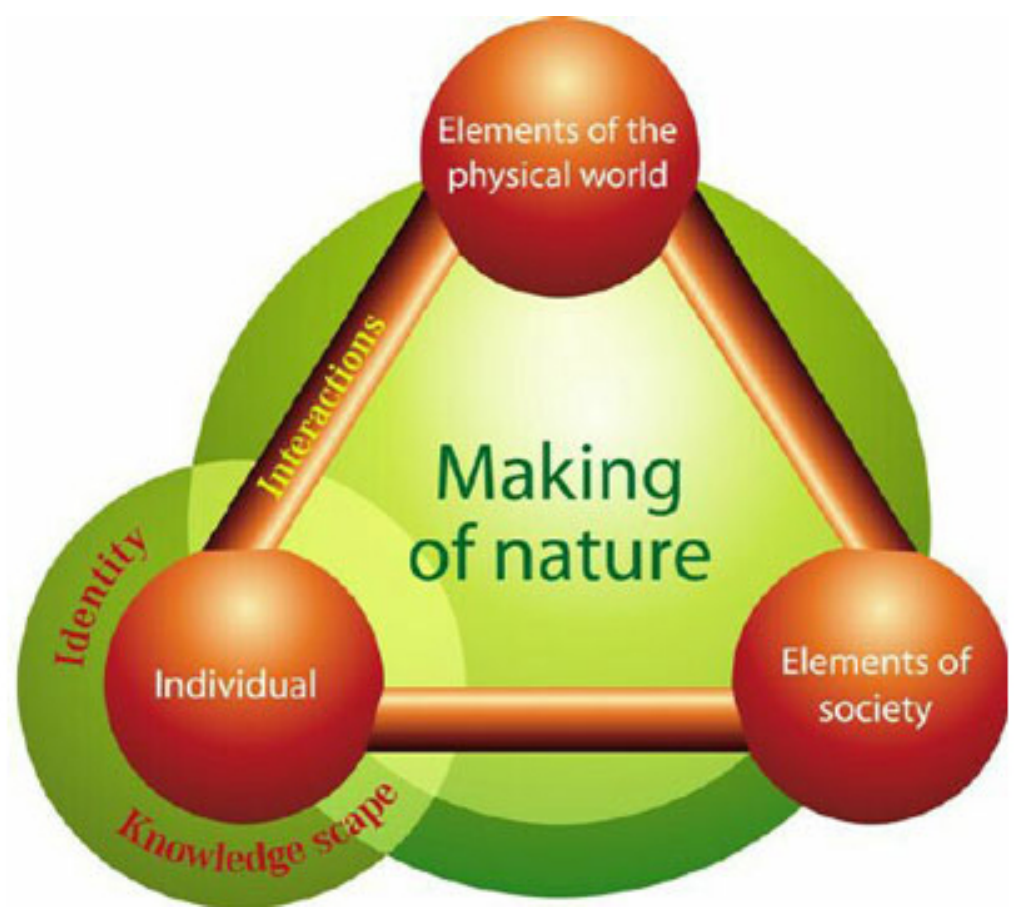

physical environment, a close relationship with a knowledge facilitator, the formal school system, and, more recently, conservation activities may be combined in various ways to form a specific knowledgescape in each instance (please see Appendix 2: Quotation 1).

The knowledgescape of two individuals from the same social group may differ substantially, in particular between two generations (Appendix 2: Quotation 2). The founding of a school, with mandatory attendance, in the Cape Horn Region in 1954 substantially changed the knowledgescape of the local residents, both Yaghan and other settlers. If a child's parents lived and worked beyond the catchment area of Puerto Williams, the child had to stay at the boarding school and could only visit his or her parents during the school holidays. Many families decided to move to Puerto Williams to be near their children. Despite this influence, some of the interviewees, on being asked how they learned about animals, birds, and plants, stated that personal experience was the most important form of knowledge transfer (Appendix 2: Quotations 3, 4). This finding is similarly demonstrated in the studies by Kaschula et al. (2005) and Cristancho and Vining (2009).

Personal contacts with parents, grandparents, and people in general whom the interviewees trusted were an important source of knowledge acquisition. Thus, the relationship with a knowledge facilitator also played a substantive role. A recent settler recounted his learning experiences as follows:

And I learned about the birds when (...) I was still at school and I went with some university students, who were like heroes for me, because they talked to me! (...) And these students allowed me to accompany them. And I was silent the whole day, I just watched what they were doing. And the next day I got myself some books and I was determined to learn everything I could about the birds.

In contrast to knowledge transfer via personal experience or familial relationship, many interviewees, mostly those who came more recently to live in the region, referred to a mediated form of knowledge transfer (Appendix 2: Quotations 5, 6). 


\section{Interactions}

We consider the various activities engaged in by the interviewees in their contact with nature to be highly significant in their relationship with nature. People's appreciation of the natural environment was clearly related to their interactions with it (Appendix 2: Quotation 7). We therefore call the second category "interactions," distinguishing further between "material interactions" and "sensory interactions," which are not mutually exclusive subcategories.

Material interactions refer to activities of the interviewees that involve direct, consumptionoriented contact with their natural environment, such as cultivating through horticulture or agriculture, livestock farming, fishery, forestry, hunting, medicine, and handicrafts. Material interactions include commercial and/or subsistencebased activities.

People's material interactions with their physical environment can also take place in an indirect way that is often associated with processes of globalization, e.g., buying Irish butter from a small shop in the south of Chile. Such interactions are often not perceived as such and therefore reinforce the already widespread decoupling of the acts of production and consumption and of relationships between the local and regional or global contexts. Further, the spatial range of such interactions varies greatly. As a young woman who was born on the Island and belongs to an old settler family put it: "I move only within my own little space, which is the village." Other settlers stated that they were mobile in many parts of the region (Appendix 2: Quotation 8).

Sensory interactions denote those activities of the interviewees in their natural surroundings that are devoid of a material aspect in the sense of consumption-based use or strong interference. These activities include observation, contemplation, leisure activities, walking, hiking, taking pictures, and even scientific fieldwork.

As mentioned above, material and sensory interactions are not mutually exclusive. Sensory interaction can also take place in conjunction with material interactions. Two examples were the fisherman who describes his appreciation of a sunrise while sailing to the fishing grounds and the following description by a resident of the Yaghan community of a chance encounter with a woodpecker:

I really like ... the woodpecker, for the call it has, apart from being beautiful to look at. Looking at it, suddenly, (...) I think it is something beautiful, sometimes in the mornings when I come back walking, and am tired, you suddenly come across a couple of these birds singing. (...) I don't know exactly, but it is like something exhilarating when... I think it is like a moment of peace that you have with it. (...) And then, you go back to the chores that you have to do.

In most of the interviews with more recent settlers, navy personnel and their families, and interviewees working for public authorities, we found a clear focus on a more intentional sensory interaction, such as: "You open the window and see a postcard, that is what I like."

\section{Identity}

The category "identity" points to those aspects of people's relationship with nature that form part of their identity. This identity can be characterized using the subcategories "relatedness" in the sense of emotional attachment (Greider and Garkovich 1994, Körner 2004) and a sense of place (Kaltenborn 1998, Williams and Stewart 1998), as well as a certain perception of nature in relation to the self. When viewed in conjunction with the knowledgescape and interaction of the inhabitants, the category "identity," which has been discussed mainly in the context of psychology to date (Clayton and Opotow 2003), offers important insights for conservation efforts.

The following quote from a man from a settler family shows how this person's relationship to nature constituted part of his identity: "I like the beaver because he came to settle and he is from here, he is from [Puerto] Williams. He is like we are. We came to settle, and now they won't take us away again."

This identity, or self-definition in relation to nature as it is called by Greider and Garkovich (1994), means that a person or a social group incorporates aspects of the natural environment into their definition of self. Hence, processes of negotiating the meaning or importance of a certain species or landscape can in fact touch upon identity issues. 
With regard to relatedness, nearly every interviewee gave expression to his or her personal relatedness to a species, (Appendix 2: Quotations 9-11), a landscape, or a place, some very specifically and others in more general terms (Appendix 2: Quotations 12-14). Some of the interviewees referred to the region as a place that is home. The aspects of the environment that form part of peoples' identity vary, because relatedness is often linked to the specific experiences of the interviewees, e.g., in a certain region, on a farm, at sea. The key point here is that the species, the place, or the landscape to which a person refers serves as a frame of reference for judgments and decisions (Appendix 2: Quotations 15-18), especially when he or she is experiencing something new or different (Appendix 2: Quotations 19, 20).

Also relevant to peoples' identity is their perception of how nature is in relation to the self. We therefore call the second subcategory "perception of nature in relation to the self."

Some interviewees perceived their physical environment as self-reliant, active, and robust (Appendix 2: Quotation 21). Those who perceived nature as self-reliant and active often did not think that their natural environment was under threat. At the same time, however, when nature was perceived as fragile and more passive in relation to humans (Appendix 2: Quotations 22, 23), the interviewees feared that nature might be threatened by human beings.

\section{Presenting narratives: the making of different natures}

In the following, we illustrate the creation of different natures in the Cape Horn Region by narrating different stories in accordance with our proposed framework. We show how the categories generated by our framework can be identified at the level of the interview data, which dimensions can be found, and how they can be assembled into specific natures. We present these stories as seven relationships with nature (see Table 2).

\section{A relationship with a global and endangered nature}

This relationship is characterized by a knowledgescape based on a global perspective and on scientific knowledge. Its main characteristic is knowledge or experience of global environmental discourse about ecological destruction, urbanization, globalization, etc. There is a strong intellectual component in which reading about nature and ecology and the possibilities of further education in relation to the natural environment are major elements.

Another factor in this relationship was the perception of being economically independent from consumption of local natural resources, as in the case of people working for the public authorities. Sensory interactions prevailed, such as recreation, exploration, taking pictures, etc. Any material interactions were decoupled from personal experiences and often unregarded. There was a separation in people's personal experience between human activities and nature; work and leisure were clearly viewed as separate activities.

When the interviewees gave an account of the species they valued, they often made reference to their conservation status as being endangered, unique, or rare. In general, nature was perceived as a global entity and as being fragile and passive in contrast to the human being. In response to the threats and dangers to nature, an alternative conception was often hinted at in which nature served to educate the human being: "To rediscover, to reorient, to renourish your perspectives with new dynamics, with new aesthetic dispositions (...). It is not a human cultural creation and it is there and you have to share it and there's no reason to dominate it, or to correct it, or to do anything with it. You are called to live it, to enjoy it."

In this alternative conception, the prevailing idea was that of a wild and untouched nature: "Where the natural realm is the kingdom and not the cultural realm and where you are the accident (...) I think the great value [of this region] is its pristine state, untouched and unaltered."

The experience of urbanization served as a frame of reference for establishing a contrast for the wife of a navy officer (Appendix 2: Quotation 24):

When I lived in Talcahuano, which was a large part of my life, and because it has always been an urban zone (...) with factories and contamination, well, the smoke of the fish factories, and noise pollution (...) So, you do not really appreciate, are not able to 
Table 2. Categories, subcategories, and dimensions characterizing people's relationships with nature in the Cape Horn Biosphere Reserve.

\begin{tabular}{|c|c|c|c|c|c|c|}
\hline \multirow[t]{2}{*}{ Relationships } & \multicolumn{2}{|c|}{ Knowledgescape } & \multicolumn{2}{|c|}{ Interaction } & \multicolumn{2}{|c|}{ Identity } \\
\hline & Elements & $\begin{array}{l}\text { Transfer and } \\
\text { background }\end{array}$ & Material & Sensory & Relatedness & $\begin{array}{l}\text { Nature in relation } \\
\text { to me }\end{array}$ \\
\hline $\begin{array}{l}\text { Global and } \\
\text { endangered nature }\end{array}$ & $\begin{array}{l}\text { Focus on } \\
\text { endangered } \\
\text { species, wild } \\
\text { and untouched } \\
\text { nature }\end{array}$ & $\begin{array}{l}\text { Scientific, global } \\
\text { perspective }\end{array}$ & $\begin{array}{l}\text { Independent } \\
\text { from local } \\
\text { resources }\end{array}$ & Predominate & $\begin{array}{l}\text { With nature } \\
\text { as global } \\
\text { entity }\end{array}$ & $\begin{array}{l}\text { Fragile and } \\
\text { passive, } \\
\text { endangered }\end{array}$ \\
\hline $\begin{array}{l}\text { Nature enjoyed } \\
\text { through the senses }\end{array}$ & $\begin{array}{l}\text { Focus on } \\
\text { beautiful } \\
\text { landscape or } \\
\text { species }\end{array}$ & $\begin{array}{l}\text { Diverse forms of } \\
\text { transfer }\end{array}$ & $\begin{array}{l}\text { Independent } \\
\text { from local } \\
\text { resources }\end{array}$ & $\begin{array}{l}\text { Predominant, } \\
\text { focus on } \\
\text { visual }\end{array}$ & $\begin{array}{l}\text { With certain } \\
\text { species and } \\
\text { landscapes }\end{array}$ & $\begin{array}{l}\text { Passive, often } \\
\text { endangered }\end{array}$ \\
\hline The beloved land & $\begin{array}{l}\text { The land, } \\
\text { (farm) animals, } \\
\text { cultivated land }\end{array}$ & $\begin{array}{l}\text { Personal } \\
\text { relations (often } \\
\text { related to other } \\
\text { parts of Chile) }\end{array}$ & $\begin{array}{l}\text { Dependent on } \\
\text { local resources }\end{array}$ & $\begin{array}{l}\text { Related to } \\
\text { material } \\
\text { interactions, } \\
\text { casual }\end{array}$ & $\begin{array}{l}\text { With } \\
\text { concrete } \\
\text { places, } \\
\text { notion of } \\
\text { home }\end{array}$ & Place where I live \\
\hline Providing nature & $\begin{array}{l}\text { Marine } \\
\text { resources }\end{array}$ & $\begin{array}{l}\text { Personal } \\
\text { experience and } \\
\text { relations }\end{array}$ & $\begin{array}{l}\text { Emphasis on } \\
\text { material } \\
\text { interactions }\end{array}$ & Little interest & Weak & $\begin{array}{l}\text { Passive, robust if } \\
\text { managed }\end{array}$ \\
\hline $\begin{array}{l}\text { Nature as a self- } \\
\text { reliant companion }\end{array}$ & $\begin{array}{l}\text { Elements that } \\
\text { are part of daily } \\
\text { life }\end{array}$ & $\begin{array}{l}\text { Personal } \\
\text { experience and } \\
\text { relations }\end{array}$ & Both, no clea & r separation & $\begin{array}{l}\text { With } \\
\text { concrete } \\
\text { local places } \\
\text { and species }\end{array}$ & $\begin{array}{l}\text { Self-reliant, } \\
\text { active, robust }\end{array}$ \\
\hline $\begin{array}{l}\text { Mediated global } \\
\text { nature }\end{array}$ & $\begin{array}{l}\text { As presented } \\
\text { by media }\end{array}$ & Media & $\begin{array}{l}\text { No direct } \\
\text { interaction }\end{array}$ & Little interest & $\begin{array}{l}\text { With } \\
\text { charismatic } \\
\text { species }\end{array}$ & Passive \\
\hline $\begin{array}{l}\text { Local nature } \\
\text { reassessed }\end{array}$ & $\begin{array}{l}\text { Focus on local } \\
\text { context }\end{array}$ & $\begin{array}{l}\text { Personal } \\
\text { relations, family } \\
\text { and also NGO, } \\
\text { scientists }\end{array}$ & Both, no clea & r separation & $\begin{array}{l}\text { With } \\
\text { concrete } \\
\text { local places } \\
\text { and species }\end{array}$ & $\begin{array}{l}\text { Fragile, threatened } \\
\text { by urbanization } \\
\text { and globalization }\end{array}$ \\
\hline
\end{tabular}

appreciate the little bit of nature that exists there (...) But when you have the opportunity, (...) and you go to a place, like the land or further south for example, where you come across tranquility, and nature, with birds, ... with a different climate, even with different people from other parts: the calm manner in which they talk, with pauses, eh ... as if there is no hurry ... all these things are like ... you learn to appreciate them when you are not in the city.
However, although the interviewees emphasized the value of the region, their identification with it as a place to call home was minimal.

\section{A relationship with a nature enjoyed through the senses}

Among the new residents, public employees, and navy family members, the relationship with a nature enjoyed through the senses was clearly dominant, with a focus on sensory interactions as the most 
common mode for relating to nature: "The ability to enjoy here: you go out, outside of the village, and you come across virgin land, natural beauty, which is marvelous and pretty. That is what I like most. Going out for a walk, going into a forest where you feel like you are the first one to be there. For me, that is nice."

Being economically independent from consuming local natural resources was likewise characteristic. The knowledgescape, however, was different from that found in the relationship with a global and endangered nature. Other elements of the physical world shaped this nature. Knowledge of specific species or of ecological interactions was not important. The aesthetic aspects of the landscape were prevalent, especially when contrasted with the city. As the wife of a navy officer explained:

It is incredible to sit down and look at the mountains in front of you. Before you looked at them on a postcard and they were really far away. To have them here is wonderful; you enjoy them day by day, as you know that later you will be ... I remember when I was sitting at the table in my mum's dining room and you couldn't see anything. You could watch TV and look at the houses and only electric cables and stuff.

According to an eight-year resident of Port Williams, there was also a focus on visual appearance:

My son has a book that he got as a gift. In it we saw that there are thousands of birds, really a lot, and all of them have names ... and I said, "But where are all of these birds that we haven't seen?" And my son said, "Mum, they are in the forest, you have to go into the forest to see them." But when you go into the forest, the forest is so big that you can't see the birds, you can hear them, but you do not see them. Or you have to be there, I don't know, waiting for hours for them to appear... Those you see here more often are those that come to the village, which are some small ones with a yellow breast.

Nature was often perceived as being endangered if there was any perceived change in this visual appearance (Appendix 2: Quotations 25, 26).
The role of human beings in relation to nature was not discussed very frequently, if at all; if it was, it was usually in terms of animal rights. Animals were mentioned more frequently than plants, of which people had very little knowledge. Those with this kind of relationship to nature often spoke in favor of nature protection, especially in relation to charismatic species. The prevailing ideal was a beautiful landscape. Identification with the place may be either strong or weak. The relationship with a nature enjoyed through the senses was the most common one and was found in all social groups.

\section{A relationship with "the beloved land"}

According to a man fom the Yaghan community: 'For me it is important. I look after the land, I make my living from it. I take care of it. I do not abuse it and I do not overexploit it in any way."

A direct material interaction with nature in combination with a strong identification with the land was the most important aspect of this relationship with nature. The notion of home was an important value. Cultivated land was the prevailing ideal. Private property and dependency on local natural resources were often associated with this relationship with nature.

The interviewees who displayed this relationship with nature often expressed their discontent with the current politics of nature protection. They viewed critically the fact that their way of living was being devalued: 'We should not cut off the hands of those who raise the cattle, of those who cultivate and of those who bring in the firewood." (Appendix 2). They felt powerless in the face of the state: "These laws and everything that always come from outside. Made by people who do not know what it means to live here."

A clear difference was perceived between "taking care of" and "protecting," as one resident stated (Appendix 2): "I cannot protect what I'm working on."

As far as the knowledgescape was concerned, personal relations in the acquisition of knowledge were important (Appendix 2: Quotation 27). Although this probably took place in the local setting, the background of this knowledge was often related to other places, because most of the people 
with this kind of relationship with nature, or their families, came from other parts of Chile or even Europe.

Being in contact with nature did not mean exploring a wild or beautiful nature, but simply being on the land, living with the (farm) animals, working, going for a walk, and enjoying the peace and quiet. Sensory interactions were not absent but were always related to material interactions.

\section{A relationship with a providing nature}

Some of the interviewees referred to nature primarily in terms of resource use. Characteristic of this type of relationship was an emphasis on material interactions and a low level of interest in sensory interactions with nature. In contrast to the relationship with a beloved land, for the following fisherman, a nine-year resident, identification with place did not play a role (Appendix 2): "I'm not interested in getting to know the island ashore, because there are only rotting tree trunks, bogs, and things that do not even resemble a forest, well ... there is only mud. That is what I think of the island. ( ... ) I don't know what you could protect on this island, because there isn't a lot here."

This man's knowledgescape was characterized by a clear focus on marine resource use, especially the extraction of king crabs and snow crabs, whereas terrestrial fauna and flora were barely mentioned. Nature was perceived as passive, and, according to another local fisherman (Appendix 2), resource use had to be regulated to maintain the functioning of the economic rather than the ecological system: "This region, especially Puerto Williams, has been a region of king crab fishermen who depended on this livelihood. (...) So, now that the king crab resource has been overexploited, we have to move on to other resources. (...) We need a whole zone, let's say like they did in Alaska: a closed season of five years."

\section{A relationship with nature as a self-reliant companion}

For one native fisherman, his relationship with nature represented a strong local perspective with material and sensory interactions (Appendix 2): "From my point of view, I'm a happier man at sea. Happier. I love it. I don't see it as a job, or a chore. Do you understand? And I also have a lot of luck [catching centolla] when I'm working at sea."
This relationship was characterized by a strong identification with place. Asked what he appreciated on this island, a fisherman from the Yaghan community answered (Appendix 2): "For me, I think, everything that is here. Everything ... everything. Because I think I could not be anywhere else. Well, I wouldn't feel comfortable anywhere else."

Among the newer residents, public employees, and navy family members, a relationship with nature as a self-reliant companion was completely absent. It was found only among those inhabitants who were born on the island or had at least spent a large part of their childhoods in the region, such as the Yaghan community and long-term residents; this relationship can thus be considered the most local one.

The interviewees did not refer to a separation between humans and nature, and the wilderness concept appeared to be nonexistent. One could say that, for those inhabitants with this relationship with nature, there was no "intellectual" approach to nature in terms of a conceptual understanding. It was uncommon to talk about nature in abstract terms. These interviews were the most difficult to conduct, because our own relationship with nature as scientists was characterized more by an intellectual approach, with few direct material interactions. It seems as if the abstract concept of nature is an intrusion that comes with tourism and/ or scientific thinking; the separation between nature and culture enters the scene as a modern phenomenon. Nature conservation and the protection of species are therefore strange concepts, and it did not seem easy for the interviewees to express themselves when confronted with them. Asked if any of the plants, animals, or birds in the region were important to him, a fisherman from the Yaghan community answered, "I think, I don't know ... for me, all of them, I think ... For me all of them are important, but I do not see how to put ..." (See also Appendix 2: Quotation 28).

Invasive species, another scientific concept, were not judged or perceived as negative, as evidenced in the following dialogue with a Yaghan fisherman about the beaver:

Question: And what do you think of the beaver? Answer: That there are many, they say.

Question: And do you like them or not? Answer: I imagine they are also okay. Yes? They also have the right to be where ... at least, 
they do not bother me. I like the beavers.

Question: Why do you like them?

Answer: Because they are peaceful, they do not

bother anyone, they do nothing, they just cut the trees...

The physical environment was taken for granted (Appendix 2: Quotation 29) when dynamics and changes were self-evident, as a Yaghan fisherman commented about the case of king crab trapping (Appendix 2): "Maybe there are years when the centolla [king crab] or the centollon [snow crab] don't move, and other years when they are on the move a lot, I don't know. Or there are years, I don't know, when they are not hungry and years when they are hungry."

This nature was self-reliant, active, and robust, as if it were a person, a partner, or something to struggle with (Appendix 2: Quotations 30, 31). Another fisherman from the Yaghan community recalled an encounter with a dolphin:

We do not touch them [the dolphins], and do you know why? They brought us bad luck. I never believed it, but a few years ago, we tried to kill one, we laid it down and we would have killed it, but our boat drifted off without us and we were left stranded, isolated, and since that day never again. There are still dolphins in the sea, but we only look at them, and now no fishermen hunt dolphins, not a single fisherman.

Often species were perceived as companions (Appendix 2: Quotation 31). One interview with a woman who recalled her childhood experiences in the Atacama desert illustrates that the natural environment can powerfully shape all aspects of everyday life. Nature was part of daily life; it was not perceived as a separate entity as is the case, for example, with many city dwellers (Appendix 2: Quotation 32).

The interviewees stated that their knowledge about natural elements and processes resulted from personal experience and was passed down from their parents and grandparents (Appendix 2: Quotations 33, 34). This knowledge was more than about names and functions; it was coupled with memories and emotions, as demonstrated in the following quote from a woman from an old settler family who was born in the region: "We always went to the same place and left the boat there. And on the shore there was always the celery. And my dad said 'This is celery, it's nice for eating.' And I tried it, and it was really nice."

Formal schooling did not play a role in the acquisition of knowledge about the region. On the contrary, one interviewee from the Yaghan community stated explicitly that he had less knowledge compared to his cousins, even though he spent more time at school than they did.

One characteristic aspect of this kind of relationship with nature was that there was no focus on private property. On the contrary, freedom of movement and the opportunity to go and work wherever you wanted were more important (Appendix 2: Quotation 34). One woman from the Yaghan community complained, "Now they make problems out of everything. Before it wasn't like that, and if you wanted you could go wherever you wanted to or hunt beavers. Now, it is not possible because you need a permit for everything."

\section{A relationship with a mediated global nature}

Some of the Navy family members interviewed had almost no direct interaction with their natural surroundings; they were not interested in the animal species (Appendix 2: Quotation 35), the material value of nature, or the beauty of the place. They lived a "city life" in every respect, and many wanted to go back to the parts of Chile that they came from. According to one officer's wife: "Personally, I'm here just for the sake of being here. And not because of how nice Williams is, I like it. No, I'm here because, well, my husband was sent down here and that was that. I haven't dedicated any time to getting acquainted with the place."

Their knowledgescape was constructed mainly through the media and mediated knowledge transfer. The nature they valued wasd created far away; they appreciate the Discovery Channel and animals that appear in comics or television series, but the surrounding environment was not important to them (Appendix 2: Quotation 36). It might be a great surprise for them to discover a living creature that they otherwise know only from television, as in the following dialogue with the wife of a naval officer about the woodpecker:

Comment: Once I saw a pájaro loco. We were out walking, together with my husband, and we could hear it. Toc, toc, toc [knocking on the 
table]. And we started looking around us, and it was a pájaro loco.

Question: What is a pájaro loco?

Answer: The woodpecker.

Question: Why do you call it a pájaro loco? Answer: Because, well, when I was a child on the TV they showed this cartoon figure, and it was called pájaro loco [Woody Woodpecker].

One temporary resident was aware of the discrepancy between mediated knowledge transfer and her own personal experience (Appendix 2): "In kindergarten they teach the children like this: very formally. Like, yes, you do it right. My grandmother or my mother would say to me, 'Try this, this is cochayuyo [the edible algae Durvillaea antarctica]. But now it is more formal, more intellectual, like a concept. More theoretical rather than doing it yourself."

A relationship with a local nature perceived in a new way

The final narrative in the creation of natures in the Cape Horn Region has to do with a reassessed local nature. In this account, the local vs. global dichotomy appears in a new light: on the one hand, local nature is valued highly and is emphasized as such, but the interviews also revealed that this valuation was strongly influenced by the global discourse mediated by conservation scientists working in Puerto Williams. A comment by a Yaghan woman provides an example of this (Appendix 2):

I learned it from Marina [of the Omora Foundation; name changed] because I didn't know. (...) I walked a lot together with my aunt when I was a child. We roamed around a lot, up the hills, everywhere. I walked and walked, traipsed everywhere I had to, but I didn't know what it was called. I didn't know until Marina ... she taught me everything. Michay [Berberis ilicifolia], michay, I had no idea which one was michay and then recently I got to know which one is michay.. (See also Appendix 2: Quotation 1).

The development of concepts such as indigenous, local, or embedded nature goes hand in hand with global conservation. Such interventions and retellings (Rozzi 2003) give birth to new forms of nature "making" that are at once global and local.
The work of scientists living in and coming to Navarino since 2000 has changed the ways in which some inhabitants of Puerto Williams relate to and value their physical environment, including one eight-year resident:

I think that we are really ignorant about the vegetation, the animals, and everything about the birds in the region. When people come from other places, they know all the names! One year, I remember, a gentleman who studied birds came here. Well, he knew every single bird, all of them (...) And he came from California, I remember (...) He came to write a book about the birds, he told me. And I said to him: "But how are there so many birds, and where are those that I don't know?"

The scientists' presence at least posed a challenge to people's previous perceptions, as in the case of this woman from an old settler family who was born in the region:

I have spent all of my life here. I also lived with my family for a while in Robalo [a place that is now the Omora Park] (...) I have been to all of those places, but I would never have thought that one day there would be an Omora Park! I know that there have been changes. And there are things that exist here, but you do not even use them, or you don't even know that they exist, and if you do know you do not value them.

The knowledge and culture of the Yaghan community, which was heavily suppressed under the Pinochet dictatorship, has gained a new significance, especially in collaboration with the conservation movement (Appendix 2: Quotations 1,38 ). The ideal of living in harmony with nature is often envisioned (Appendix 2: Quotation 39), in which a revalued local indigenous culture plays a leading role (Appendix 2: Quotation 40).

\section{Conflicting natures?}

We have shown that several natures co-exist in the Cape Horn Region. However, their respective influence within the wider societal discourse varies considerably. The Cape Horn region has seen a succession of periods of colonization with their ensuing social structures, beginning with the indigenous population and followed by missionaries 
and settlers during the 19th and 20th centuries. Different waves of settlement, the establishment of a Chilean naval base in Puerto Williams, and the onset of globalization in terms of tourism and export fisheries have all left their imprint on different peoples' knowledgescapes, patterns of interaction, and identities in relation to nature.

Prior to 1990, especially during the military dictatorship, the influence of the navy was dominant in the region. The dictum during this period was hacer soberanía, i.e., to consolidate Chilean national sovereignty by developing the remote regions of the nation's territory. As a result, a relationship with the beloved land was promoted that dominated the discourse, because cultivating the land meant taking control of it. After the return of democracy, free land concessions were granted to old settler families in recognition of their pioneering efforts (Berghöfer 2002).

Today, the ideal of the beloved land has lost its appeal. On the one hand, the export-oriented fishery has attracted modern processing facilities, reflecting a more industrialized use of a providing nature. On the other, expanding international tourism has led to a new appreciation of the relatively untouched landscape, with the wilderness ideal becoming popular. The new ideal is projected onto those areas that were formerly closed and controlled by the navy, and there is now a common understanding and a potential for unusual alliances between Chilean conservationists and the navy.

However, the wilderness ideal, as a global discourse propagated by many conservationists and adopted by the nature tourism industry active in the subAntarctic region, frequently comes into serious conflict with the different natures perceived by the local residents. The relationship with the beloved land conflicts most with the relationship with a global and endangered nature, mainly in terms of people's identification with place but also in the different weighting of material and sensory interactions and their divergent knowledgescapes. Communication between them is very difficult, and what nature is to be protected from is perceived from very different standpoints. Those who have a relationship with the beloved land feel that they are being unjustly held responsible for its destruction (Appendix 2: Quotation 41). From the global perspective of an endangered nature, although the intention is not to blame local land users, the people's material interactions with their surroundings are often equated with destructive resource use, whereas aspects of relatedness and personal identity are neglected because they seem irrelevant from this global perspective. Instead, the remaining wilderness areas are to be protected from further destruction for the sake of humanity. Only local traditional or indigenous land-use practices are valued, but these categories are defined by outsiders. A Yaghan fisherman, for example, rejected such external rationales by saying: "I' $m$ not an Indian." The relationship with a local nature perceived in a new way has often been adopted in response to the global rationale of an endangered nature and is obviously compatible with this type. Clear distinctions between local and global or between global and scientific knowledge become obsolete because local knowledge is strongly intermingled with global knowledge.

The role of invasive species serves as an illustrative example (Appendix 2: Quotations 42-44) in which we find global and endangered nature opposing the beloved land or a nature enjoyed through the senses. The dense population of Canadian beaver (Castor canadensis) is one of the most controversial topics in the Cape Horn Region. Although this animal is perceived as an invasive species and as a serious threat to a global and endangered nature, it is valued by many inhabitants as a charismatic species (Appendix 2: Quotation 43). Some people identify with the beaver, which also serves as a mascot for the local municipality, or emphasize its right to live. Others simply appreciate the beaver as one of the few larger mammals in the region. Neglecting these attitudes toward a contested species can quickly lead to confrontations on the whole topic of conservation. The use of military expressions, e.g., "We will move in on the beavers in a rolling front" (Choi 2008:968), sharpens the confrontation. Rather than reducing the goal of conservation to the extremes of the current black-or-white conflict, one possibility would be to discuss more specific and differentiated regulations. A more adequate description of the situation to be managed might be obtained by including aspects such as local people's appreciation of the animal, options for tourism development, notions of home, new sources of income, remaining wilderness area, and ancient forests as the home of the endangered woodpecker, among others. 


\section{DISCUSSION: FROM SOCIETAL RELATIONSHIPS WITH NATURE TO CONSERVATION PRACTICES}

For protected areas, the above considerations imply that there is no such thing as the one and only nature in need of protection. Different natures emphasize and value different aspects of physical reality. Laying them out clearly makes it possible to negotiate the associated ideas about what constitutes an intact nature that is to be protected. It thus becomes possible to render operational Principle 1 of the Ecosystem Approach of the Convention on Biological Diversity (UNEP/CBD 2000:104), a task that has proved to be far from trivial (Shepherd 2008).

The world views or cosmologies of local inhabitants are often treated as alternative constructions superimposed upon the "real" reality of nature, which can only be fully understood from a scientific or international conservation perspective (Ingold 2000). Analyzing and respecting relationships with nature in different contexts, including the scientific, can lead to alternative conservation solutions. "Since much conservation work seemed to be undermining and displacing local communities, livelihoods and lifeworlds" (Igoe and Sullivan 2008:3), our approach is intended to help reorient conservation efforts to cease perpetuating inequality in many parts of the world.

A number of practical consequences may be derived from this. First, it is important that decision-making processes should include participatory dimensions, thus enabling the inclusion of different natures. Developing and implementing such processes is far from straightforward (Goodwin 1998, Hickey and Mohan 2004, Berghöfer and Berghöfer 2006). Not only must they be tailored to the specific societal and natural conditions of an area in terms of both form and content, but they must also accommodate an attentiveness to those perspectives that are not officially organized or represented or are barely visible in policy discourse, as is the case with the relationship with nature as a self-reliant companion in the context of the Cape Horn Biosphere Reserve. The criteria for what constitutes "local traditional" or "indigenous" can be spelt out explicitly for purposes of transparency.

There is a trend toward integrating local/traditional ecological knowledge in research and conservation projects (UNEP 1998, Berkes et al. 2000, WCPA
2000, 2004, IUCN 2005, UN 2007, Brook and McLachlan 2008). So far, however, efforts to elucidate and integrate different types of knowledge have often been simplistic and dichotomous, such as the notions of local vs. global knowledge (Mohan and Stokke 2000, Brosius 2004, Nazarea 2006), or indigenous vs. nonindigenous knowledge (Agrawal 1995, Sillitoe 1998, Briggs and Sharp 2004, Briggs 2005). The basic categories of knowledgescape, interactions, and identity seem very suitable for guiding empirical inquiry into the facets of societal relationships with nature in a specific setting. Although there are only three of these categories, they capture a broad range of aspects that are valid independent of cultural context. Consequently, our framework can serve as a heuristic tool to characterize the diverse ways in which local people make sense of their environments and assist in analyzing local knowledge as heterogeneous ways of knowing (Nygren 1999). Our findings underline the fact that there is no single relationship with nature that corresponds directly to a certain social group on a one-to-one basis (Atran et al. 2002, Ghimire et al. 2004). For example, no homogenous indigenous relationship with nature could be found among the members of the Yaghan community. To avoid conflicts over representation it is crucial to make explicit what and who counts as local and who is empowered to speak on their behalf (Agrawal and Gibson 1999, Brosius 2004).

This would help to overcome some of the limitations of current participation processes by opening up new perspectives on ongoing or hidden conflicts and by emphasizing that natures are created in a certain social and physical context and are not given a priori. The focus on relationships implies that dynamics, changes, and political relations are part of the game, and that the making of nature goes hand in hand with the formation of social institutions (Agrawal 2005).

A second consequence of acknowledging different relationships with nature relates to environmental education as one of the main instruments of conservation. From the perspective of societal relationships with nature, it is important to clarify precisely whose knowledge about which nature is to be transmitted in what way. Our results show how important the forms of transmission and acquisition are for the different societal relationships with nature (Kaschula et al. 2005, Roué 2006, Cristancho and Vining 2009). Which elements of the physical world are dealt with and whether emotional aspects 
or material interactions form part of the learning process varies enormously between the different forms of transmission. The debate about flagship species (Simberloff 1998, Walpole and LeaderWilliams 2002, Rozzi et al. 2006b, Arango et al. 2007, Lorimer 2007) reflects the importance of incorporating aethetics and emotions into conservation. The relationship with a nature enjoyed through the senses, which was found in all social groups, might likewise prove to be a useful communicative bridge between different groups and stakeholders. However, as familiarity with a species or a landscape, for example, may vary considerably, a one-size-fits-all approach should be treated with caution. Equally, a shared emotional attachment to a certain species or a certain place may serve as a starting point for recognizing and discussing divergent relationships, as with the woodpecker, for example, as a daily companion at work in the forest or as a species known mainly from television.

A third consequence is to reconsider the zoning concept of biosphere reserves. The different zones can be used to facilitate different relationships with nature in different parts of the area. The zoning scheme of a biosphere reserve, which normally has core zones, buffer zones, and a transition zone, allows for much flexibility in management. However, the management objectives for different zones often remain vague, and their potential to accommodate multiple goals is not fully exploited (Neumann 1997, Naughton-Treves et al. 2005, Ishwaran 2008). Taking into account the specific natures in a given context helps to determine more systematically the purpose of, and ensuing management measures for, the buffer and transition zones. This would allow for even more site-specific management measures that respect different ways of living, especially if conflicting relationships with nature are involved. The idea of shifting zonings or "multiple dynamic boundaries" (Zimmerer 2000) that temporarily restrict certain land uses, instead of fixing a land-use zone, takes into account physical dynamics and unpredictability, which is particularly emphasized in relationships with nature as a selfreliant companion (see above, Appendix 2, Berkes et al. 2000). Instead of viewing the buffer zone in purely ecological terms, i.e., as a means of protecting the core against external influences, and the transition zone merely in terms of sustainable resource use, the zones could be selected, named, and equipped with goals and rules that reflect and promote a variety of different relationships with nature.

\section{CONCLUSION}

What we emphasize here is not a way of mediating between different perspectives on one single nature, but a way of making transparent how different modes of living in the physical world engender different natures. Our research has revealed that the typical dichotomy between use and protection has little explanatory relevance if it is not specified which or whose nature is to be used and from what it is to be protected. In addition to resource use, other material interactions, sensory interactions, identityrelated aspects, and modes of knowledge acquisition shape people's relationships with nature. Hence, they can inform conservation efforts and provide a differentiated view of local knowledge. Although the dimensions may differ, the basic categories of our framework can be applied as a heuristic tool in other conservation contexts. As a procedural approach, our framework aids analysis of a complex social situation in the context of conservation efforts and makes it possible to uncover potential conflicts that might arise. Finally, taking into account societal relationships with nature also forces the scientists involved to reflect on their own assumptions and helps to create more transparency in the discussion about the goals and criteria of conservation science. We are convinced that many eyes make many natures, and that these many natures constitute a valuable heritage linking the cultural and biological diversity of our world.

Responses to this article can be read online at: http://www.ecologyandsociety.org/voll5/iss1/art18/ responses/

\section{Acknowledgments:}

The authors are grateful for the support of many colleagues from the Omora Foundation, the University of Magallanes, and the Institute of Ecology and Biodiversity (IEB), Chile. We especially thank Cristina Zarraga, Gudrun Pollack, Eduardo Barros, and all our interviewees for their time and trust. Augustin Berghöfer, Heidi Wittmer, Christoph Görg, and Felix Rauschmayer provided many valuable comments on the manuscript. We also thank the three anonymous reviewers of our paper for their constructive and detailed remarks and suggestions. We appreciate the support of the BIOKONCHIL project "Evaluation of biological diversity under the perspective of the Ecosystem 
Approach of the Convention on Biological Diversity on the basis of the case study of the island Navarino," (FKZ 01LM0208, German Ministry of Education and Research) and of the ICM, PO2-051FICM, and CONICYT PFB23-2008 projects.

\section{LITERATURE CITED}

Adams, W. M. 2004. Against extinction; the story of conservation. Earthscan, London, UK.

Adams, W. M., R. Aveling, D. Brockington, B. Dickson, J. Elliott, J. Hutton, D. Roe, B. Vira, and W. Wolmer. 2004. Biodiversity conservation and the eradication of poverty. Science 306:1146-1149.

Adams, W. M., and J. Hutton. 2007. People, parks and poverty: political ecology and biodiversity conservation. Conservation and Society 5 (2):147-183.

Agrawal, A. 1995. Dismantling the divide between indigenous and scientific knowledge. Development and Change 26(3):413-439.

Agrawal, A. 2005. Environmentality; technologies of government and the making of subjects. Duke University Press, Durham, North Carolina, USA.

Agrawal, A., and C. C. Gibson. 1999. Enchantment and disenchantment: the role of community in natural resource conservation. World Development 27(4):629-649.

Agrawal, A., and K. Redford. 2009. Conservation and displacement: an overview. Conservation and Society 7(1):1-10.

Arango, X., R. Rozzi, F. Massardo, C. B. Anderson, and T. Ibarra. 2007. Descubrimiento e implementación del pájaro carpintero gigante (Campephilus magellanicus) como especie carismática: una aproximación biocultural para la conservación en la Reserva de Biosfera Cabo de Hornos. Magallania 35(2):71-88.

Arcese, P., and A. R. E. Sinclair. 1997. The role of protected areas as ecological baselines. Journal of Wildlife Management 61(3):587-602.

Atran, S., D. Medin, N. Ross, E. Lynch, V. Vapnarsky, E. Ucan Ek', J. Coley, C. Timura, and M. Baran. 2002. Folk ecology, cultural epidemiology, and the spirit of the commons. Current Anthropology 43(3):421-450.

Becker, E., and T. Jahn. 2005. Societal relations to nature; outline of a critical theory in the ecological crisis. [online] URL: http://www.isoe.de/ftp/darms tadttext engl.pdf.

Becker, E., and T. Jahn. 2006. Soziale Ökologie; Grundzüge einer Wissenschaft von den gesellschaftlichen Naturverhältnissen. Campus Verlag, Frankfurt, Germany.

Berghöfer, U. 2002. Zur Partizipation der lokalen Bevölkerung bei der Implementierung der Biodiversitätskonvention-Das Beispiel des geplanten Biosphärenreservates Cabo de Hornos (Südchile). Thesis. Institute of Geography, University of Bonn, Bonn, Germany.

Berghöfer, U., and A. Berghöfer. 2006. 'Participation\&\#8217 in development thinking; coming to grips with a truism and its critiques. Pages 79-116 in S. Stoll-Kleemann and M. Welp, editors. Stakeholder dialogues in natural resources management; theory and practice. Springer Verlag, Heidelberg, Germany.

Berkes, F. 2004. Rethinking community-based conservation. Conservation Biology 18(3):621-630.

Berkes, F., J. Colding, and C. Folke 2000. Rediscovery of traditional ecological knowledge as adaptive management. Ecological Applications $\mathbf{1 0}$ (5):1251-1262.

Borrini-Feyerabend, G., Pimbert, M., Farver, M. T., Kothari, A., and Y. Renard. 2004. Sharing power; learning by doing in co-management of natural resources throughout the world. Cenesta, Tehran, Iran.

Braun, B., and Castree, N. 1998. Remaking reality; nature at the millennium. Routledge, New York, New York, USA.

Briggs, J. 2005. The use of indigenous knowledge in development: problems and challenges. Progress in Development Studies 5(2):99-114.

Briggs, J., and J. Sharp. 2004. Indigenous knowledges and development: a post-colonial caution. Third World Quarterly 25(4):661-676. 
Brockington, D., and J. Igoe. 2006. Eviction for conservation-a global overview. Conservation and Society 4(3):424-470.

Brockington, D., J. Igoe, and K. Schmidt-Soltau. 2006. Conservation, human rights, and poverty reduction. Conservation Biology 20(1):250-252.

Brockington, D., and K. Schmidt-Soltau. 2004. The social and environmental impacts of wilderness and development. Oryx 38(2):140-142.

Brook, R. K., and S. M. McLachlan. 2008. Trends and prospects for local knowledge in ecological and conservation research and monitoring. Biodiversity Conservation 17:3501-3512.

Brosius, J. P. 2004. What counts as local knowledge in global environmental assessments and conventions? [online] URL: http://www.millennium assessment.org/documents/bridging/papers/Brosius. peter.pdf.

Callicott, J. B., and M. P. Nelson, editors. 1998. The great new wilderness debate. University of Georgia Press, Athens, Georgia, USA.

Campbell, L. M., and A. Vainio-Mattila. 2003. Participatory development and community-based conservation: opportunities missed for lessons learned? Human Ecology 31(3):417-437.

Castree, N., and B. Braun, editors. 2001. Social nature; theory, practice, and politics. WileyBlackwell, Oxford, UK.

Cernea, M. M., and K. Schmidt-Soltau. 2006. Poverty risks and national parks: policy issues in conservation and resettlement. World Development 34 (10):1808-1830.

Chapin, M. 2004. A challenge to conservationists. World Watch 17(6):17-31.

Charmaz, K. 2006. Constructing grounded theory; a practical guide through qualitative analysis. Sage, Thousand Oaks, California, USA.

Choi, C. 2008. Tierra del Fuego - the beavers must die. Nature 453:968.

Clayton, S., and S. Opotow. 2003. Identity and the natural environment; the psychological significance of nature. MIT Press, Cambridge, Massachusetts, USA.
Crist, E. 2004. Against the social construction of nature and wilderness. Environmental Ethics 26 (1):5-24.

Cristancho, S., and J. Vining. 2009. Perceived intergenerational differences in the transmission of traditional ecological knowledge in two indigenous groups from Colombia and Guatemala. Culture Psychology 15:229.

Cronon, W., editor. 1995. Uncommon ground; rethinking the human place in nature. Norton, New York, New York, USA.

Demeritt, D. 2002. What is the "social construction of nature?" A typology and sympathetic critique. Progress in Human Geography 26:767-790.

Dowie, M. 2009. Conservation refugees; the hundred-year conflict between global conservation and native people. MIT Press, Cambridge, Massachusetts, USA.

Escobar, A. 1998. Whose knowledge, whose nature? Biodiversity, conservation and the political ecology of social movements. Journal of Political Ecology 5:53-82.

Fisher, B., and T. Christopher. 2007. Poverty and biodiversity: measuring the overlap of human poverty and the biodiversity hotspots. Ecological Economics 62:93-101.

Ghimire, S. K., D. McKey, and Y. AumeeruddyThomas. 2004. Heterogeneity in ethnoecological knowledge and management of medicinal plants in the Himalayas of Nepal: implications for conservation. Ecology and Society 9(3):6. [online] URL: http://www.ecologyandsociety.org/vol9/iss3/ art6/.

Gómez-Pompa, A., and A. Kaus. 1992. Taming the wilderness myth. BioScience 42(4):271-279.

Goodwin, P. 1998. "Hired hands" or "local voice": understandings and experience of local participation in conservation. Transactions of the Institute of British Geographers 23:481-499.

Görg, C. 2003. Regulation der Naturverhältnisse. Zu einer kritischen Theorie der ökologischen Krise. Verlag Westfälisches Dampfboot, Münster, Germany. 
Görg, C. 2004. The construction of societal relationships with nature. Poiesis und Praxis 3:22-36.

Görg, C. 2010. Societal relationships with nature; a dialectical approach to environmental politics. In A. Biro, editor. Critical ecologies. University of Toronto Press, Toronto, Ontario, Canada, in press.

Greider, T., and L. Garkovich. 1994. Landscapes: the social construction of nature and the environment. Rural Sociology 59(1):1-24.

Hacking, I. 1999. The social construction of what? Harvard University Press, Cambridge, Massachusetts, USA.

Haraway, D. 1991. Simians, cyborgs and women: the reinvention of nature. Routledge, New York, New York, USA.

Haraway, D. 2008. When species meet. University of Minnesota Press, Minneapolis, Minnesota, USA.

Hickey, S., and G. Mohan, editors. 2004. Participation: from tyranny to transformation? Exploring new approaches to participation. Zed Books, London, UK.

Hinchliffe, S. 2007. Geographies of nature; societies, environments, ecologies. Sage, Thousand Oaks, California, USA.

Hinchliffe, S. 2008. Reconstituting nature conservation: towards a careful political ecology. Geoforum 39:88-97.

Igoe, J., and S. Sullivan. 2008. Problematizing neoliberal biodiversity conservation: displaced and disobedient knowledge. [online] URL: http://www. iied.org/pubs/pdfs/G02526.pdf.

Infield, M. 2001. Cultural values: a forgotten strategy for building community support for protected areas in Africa. Conservation Biology 15 (3):800-802.

Ingold, T. 2000. The perception of the environment: essays on livelihood, dwelling and skill. Routledge, London, UK.

Ishwaran, N., A. Persic, and N. Hoang Tri. 2008. Concept and practice: the case of UNESCO biosphere reserves. International Journal of
Environment and Sustainable Development 7 (2):118-131.

Jorgensen, D. L. 1989. Participant observation: a methodology of human studies. Sage, Thousand Oaks, California, USA.

Kaltenborn, B. P. 1998. Effects of sense of place on responses to environmental impacts. Applied Geography 18(2):169-189.

Kaschula, S. A., W. E. Twine, and M. C. Scholes. 2005. Coppice harvesting of fuelwood species on a South African common: utilizing scientific and indigenous knowledge in community-based natural resource management. Human Ecology 33 (3):387-418.

Körner, S. 2004. Naturbilder und Heimatideale in Naturschutz und Freiraumplanung. Pages 77-103 in L. Fischer, editor. Projektionsfläche Natur. Zum Zusammenhang von Naturbildern und gesellschaftlichen Verhältnissen. University Press, Hamburg, Germany.

Latour, B. 1993. We have never been modern. Harvard University Press, Cambridge, Massachusetts, USA.

Latour, B. 2004. Politics of nature: how to bring the sciences into democracy. Harvard University Press, Cambridge, Massachusetts, USA.

Locke, H., and P. Dearden. 2005. Rethinking protected area categories and the new paradigm. Environmental Conservation 32(1):1-10.

Lorimer, J. 2007. Nonhuman charisma. Environment and Planning D: Society and Space 25:911-932.

Maffi, L., editor. 2001. On biocultural diversity; linking language, knowledge and the environment. Smithsonian Institution Press, Washington, D.C., USA.

Matthiesen, U. 2005. Knowledgescapes; pleading for a knowledge turn in socio-spatial research. Working Paper. Leibniz-Institut for Regional Development and Structural Planning (IRS), Erkner, Germany.

Mohan, G., and K. Stokke. 2000. Participatory development and empowerment: the danger of localism. Third World Quarterly 21(2):247-268. 
Naughton-Treves, L., M. Buck Holland, and K. Brandon. 2005. The role of protected areas in conserving biodiversity and sustaining local livelihoods. Annual Review of Environmental Resources 30:219-252.

Nazarea, V.D. 2006. Local knowledge and memory in biodiversity conservation. Annual Review of Anthropology 35:317-335.

Neumann, R. P. 1997. Primitive ideas: protectedarea buffer zones and the politics of land in Africa. Development and Change 28:559-582.

Nelson, M. P., and J. B. Callicott, editors. 2008. The wilderness debate rages on. University of Georgia Press, Athens, Georgia, USA.

Nygren, A. 1999. Local knowledge in the environment-development discourse; from dichotomies to situated knowledges. Critique of Anthropology 19(3):267-288.

Oelschlaeger, M. 1991. The idea of wilderness. Yale University Press, New Haven, Connecticut, USA.

Pedynowski, D. 2003. Science(s)—which, when and whose? Probing the metanarrative of scientific knowledge in the social construction of nature. Progress in Human Geography 27(6):735-752.

Posey, D. A., editor. 1999. Cultural and spiritual values of biodiversity. Intermediate Technology, London, UK.

Redford, K. H., J. G. Robinson, and W. M. Adams. 2006. Parks as shibboleths. Conservation Biology 20(1):1-2.

Roué, M. 2006. Healing the wounds of school by returning to the land: Cree elders come to the rescue of a lost generation. International Social Science Journal 58(187):15-24.

Rozzi, R., editor. 2003. Multi-ethnic bird guide of the austral temperate forests of South America. Ediciones de la Universidad de Magallanes, Punta Arenas, Chile.

Rozzi, R., F. Massardo, A. Berghöfer, C. Anderson, A. Mansilla, M. Mansilla, J. Plana, U. Berghöfer, P. Araya, and E. Barros. $2006 a$.
Reserva de Biosfera Cabo de Hornos. Ediciones de la Universidad de Magallanes, Punta Arenas, Chile.

Rozzi, R., Massardo, F., Anderson, C. B., Heidinger, K., and J. A. Silander. 2006b. Ten principles for biocultural conservation at the southern tip of the Americas: the approach of the Omora Ethnobotanical Park. Ecology and Society 11(1): 43. [online] URL:http://www.ecolog yandsociety.org/vol11/iss1/art43/.

Runte, A. 1997. National parks; the American experience. University of Nebraska Press, Lincoln, Nebraska, USA.

Sanderson, S. E., and K. H. Redford. 2003. Contested relationships between biodiversity conservation and poverty alleviation. Oryx $\mathbf{3 7}$ (4):389-390.

Sanderson, S. E., and K. H. Redford. 2004. The defence of conservation is not an attack on the poor. Oryx 38(2):146-147.

Sanderson, S. E., and K. H. Redford. 2006. No roads, only directions. Conservation and Society 4 (3):379-382.

Sarkar, S. 1999. Wilderness preservation and biodiversity conservation; keeping divergent goals distinct. BioScience 49(5):405-412.

Shelford, V. 1943. Twenty-five year effort at saving nature for scientific purposes. Science 98:280-281.

Shepherd, G., editor. 2008. The ecosystem approach; learning from experience. IUCN, Gland, Switzerland.

Sillitoe, P. 1998. The development of indigenous knowledge. Current Anthropology 39(2):223-252.

Simberloff, D. 1998. Flagships, umbrellas, and keystones: Is single-species management passé in the landscape era? Biological Conservation $\mathbf{8 3}$ (3):247-257.

Sinclair, A. R. E. 1998. Natural regulation of ecosystems in protected areas as ecological baselines. Wildlife Society Bulletin 26(3):399-409.

Soulé, M. E., and G. Lease, editors. 1995. Reinventing nature? Responses to postmodern 
deconstruction. Island Press, Washington, D.C., USA.

Stewart, D. W. 1990. Focus groups: theory and practice. Sage, Thousand Oaks, California, USA.

Strauss, A., and J. Corbin. 1998. Basics of qualitative research; techniques and procedures for developing grounded theory. Sage, Thousand Oaks, California, USA.

Terborgh, J. 2004. Reflections of a scientist on the World Parks Congress. Conservation Biology 18 (3):619-620.

Thompson, C. 2002. When elephants stand for competing philosophies of nature: Amboseli National Park, Kenya. Pages 166-190 in J. Law and A. Mol, editors. 2002. Complexities; social studies of knowledge practices. Duke University Press, Durham, North Carolina, USA.

Thrift, N. 2005. From born to made: technology, biology and space. Transactions of the Institute of British Geographers 30:463-476.

Tjossem, S. F. 1994. Preservation of nature and academic respectability: tensions in the Ecological Society of America, 1915-1979. Thesis. Cornell University, Ithaca, New York, USA.

UN. 2007. United Nations declaration on the rights of indigenous peoples. [online] URL: http://www.u n.org/esa/socdev/unpfii/documents/DRIPS en.pdf

UNEP. 1998. Report of the Workshop on the Ecosystem Approach, Malawi. [online] URL:http:// www.cbd.int/doc/meetings/cop/cop-04/information/ cop-04-inf-09-en.pdf.

UNEP/CBD. 2000. Ecosystem approach. pages 103-109 in Appendix 3. Decisions adopted by the conference of the parties to the convention on biological diversity at its fifth meeting. [online] URL: http://www.cbd.int/doc/decisions/COP-05-decen.pdf.

Walpole, M. J., and N. Leader-Williams. 2002. Tourism and flagship species in conservation. Biodiversity and Conservation 11:543-547.

West, P., J. Igoe, and D. Brockington. 2006. Parks and peoples: the social impact of protected areas. Annual Review of Anthropology 35:251-277.
Whatmore, S. 2002. Hybrid geographies: natures, culture, spaces. Sage, Thousand Oaks, California, USA.

Williams, D. R., and S. I. Stewart. 1998. Sense of place: an elusive concept that is finding a home in ecosystem management. Journal of Forestry 96:18-23.

World Commission on Protected Areas (WCPA). 2000. Indigenous and traditional peoples and protected areas; principles, guidelines and case studies. Best Practice Protected Area Guidelines Series, Number 4. IUCN, Gland, Switzerland.

World Commission on Protected Areas (WCPA). 2004. Indigenous and local communities and protected areas: towards equity and enhanced conservation; guidance on policy and practice for co-managed protected areas and community conserved areas. Best Practice Protected Area Guidelines Series, Number 11. IUCN, Gland, Switzerland.

World Conservation Union (IUCN). 2003. Fifth World Parks Congress recommendations. IUCN, Gland, Switzerland.

World Conservation Union (IUCN). 2005. Benefits beyond boundaries; proceedings of the Fifth World Parks Congress. World Conservation Union, Gland, Switzerland.

World Conservation Union (IUCN). 2008. Guidelines for applying protected area management categories. [online] URL: http://data.iucn.org/dbtwwpd/edocs/PAPS-016.pdf.

Zimmerer, K. S. 2000. The reworking of conservation geographies: nonequilibrium landscapes and nature-society hybrids. Annals of the Association of American Geographers 90 (2):356-369.

Zimmerer, K. S., editor. 2006. Globalization and new geographies of conservation. University of Chicago Press, Chicago, Illinois, USA. 


\section{APPENDIX 1. DETAILS ON METHODS}

\section{Our position}

We identify ourselves as scientists with an affinity for nature conservation. Being aware of the fact that our own relationship with nature would inevitably play a role in the interpretation of the interviews, we had constantly to reflect on our own position. One important question that we asked ourselves during the analysis was: What might be different between the relationships of our interviewees with nature compared with our own? At the beginning, we felt a bias toward relationships that were protective of nature, so we had to take a step back and concentrate more on existing complexities without falling into the trap of simply constructing "otherness."

\section{Interviewees}

We conducted 68 interviews with 69 inhabitants between 2004 and 2006; two people were interviewed six times and five were interviewed twice (2004 and 2005). The interviewees belonged to the following social groups:

- residents: 25 individuals (nine women and 16 men, nine of them fishermen),

- Yaghan community: 12 individuals (five women and seven men, three of them fishermen),

- navy: 17 individuals (one naval commander, one priest, five naval officers, 10 women), and

- $\quad$ public employees working for public authorities: 15 individuals (six women and nine men). Focus groups and participant observation

The focus groups were conducted with the aim of learning how the respondents talk about nature in the Cape Horn Biosphere Reserve, as a means of informing the interpretive analysis of the data obtained from the individual interviews (Stewart 1990). To cover a range of possible discussions, the participants invited were chosen from different social and organizational groups:

- tourism,

- members of social associations (neighbors, mothers),

- fishermen from the fishermen's union, and

- residents.

Three of the focus groups were conducted at the regional university (Universidad de Magallanes). Oral invitations were issued to the participants. One focus group was conducted at a local bar when it was closed, because one of the participants was the owner. The topics that were discussed included, for example, the relevance of the natural environment for tourism, the importance of access to land titles, conservation strategies, and relatedness to place.

Participant observation denotes the attempt to co-observe a subject's everyday world from his or her point of view (Jorgensen 1989). Participant observation was important because it helped us to experience the daily life of the inhabitants, especially in cases in which the interviews did not reveal sufficient information about their activities in relation to nature, and to understand better the information gained from the interviews. Participant observation also helped us to develop a familiarity with and a nuanced understanding of context. Trips out with members of the Yaghan community and with fishermen were very important, because it was difficult to communicate with them about nature, which 
they perceive as something that is self-evident and requires no special naming. The aim was to become directly involved as a participant, with direct observation as the primary method used to gain an understanding of how people make sense of nature in their daily lives. We also assisted in public meetings and teaching activities at the local school and had many informal meetings with members of the Yaghan community.

\section{Details about the setting}

All the interviews were conducted face to face and took place at the homes of the interviewees, except for three interviews that took place at the interviewees' offices. For each interview an initial contact was made beforehand to arrange a place and time.

To enlist the cooperation of the navy, we asked for official support for the interviews and obtained an official letter of permission to conduct them. Once we had this permit, more families were willing to participate, although several interviews that had been arranged could not take place because of the navy's irregular work schedules. The interviews developed in different ways: Some took only 30 minutes, because the interviewees stuck close to the questions they were asked, whereas others were more conversational and took up to $2 \mathrm{~h}$.

One extremely important aspect for a favorable interview situation and intensive, open communication was trust. Some people were willing to talk about very personal experiences. Although it is difficult to define exactly what engenders communication based on trust, several aspects can be named: a sound knowledge of the local situation, familiarity with the region over a longer period and a shared experience of everyday situations such as energy problems, explaining the background of the interviews to the participants, an honest interest in the perspectives of the participants, adapting the interview situation to the participant's experience, and trying to make the interview situation as comfortable and relaxed as possible.

A sample of the interview questions that guided the semistructured interviews is presented in Appendix 3 .

Eleven interviews were conducted by Gudrun Pollack, and the other interviews and focus groups were conducted by Uta Berghöfer.

Initial sampling and coding

All interviews were transcribed literally in Spanish. The first coding process was manual, word by word and line by line, using paper and pencil. The first interviews were discussed in several working sessions involving between two and four participants. Coding was subsequently carried out using MAXQDA software (VERBI GmbH., Marburg, Germany).

For the initial sampling, the criterion for selecting interviewees was the social group to which they belonged. First we interviewed individuals from each group: the Yaghan community, public employees, residents, and navy personnel.

The first phase of the coding process included a word-by-word analysis of a few selected phrases to address images and meanings; this constituted a first analytic step. An example of such an analysis is presented in Appendix 4 for the sentence "Everything is valuable, everything that is natural, because everything is a harmonious whole, there is nothing that is dispensable; the only thing that is dispensable is the human being." The first codes that emerged were focused on the images and appreciation of nature or natural elements to which the interviewees made reference. It soon became clear that childhood and learning experiences played a significant role. In addition, one particular question arose that led to the second interview phase: How are the activities engaged in by the interviewees in and with nature related to their appreciation of nature? 
Theoretical sampling and focused coding

The purpose of theoretical sampling is to obtain data that help explain the categories emerging from the initial coding process. The second phase of data collection focused on different activities and childhood experiences. The interviewees were selected on the basis of a supposed difference in their activities in relation to nature to find contrasting cases. A third interview phase focused on fishermen, because their activities and relationships with nature had not been sufficiently understood.

The process of analysis and coding is characterized by switching constantly between the phenomena, $\mathrm{i}$. e., the concrete interview data, and the theoretical level and thus by switching between different coding strategies. At the end of the analysis, line-by-line coding was still conducted wherever this was deemed necessary. A complete mapping of the coding process in its chronology is neither possible nor essential. To allow for transparency and credibility we present our results in two ways. First, we present our framework and then we describe the case histories or types from the perspective of our framework. 


\section{APPENDIX 2. QUOTATIONS}

Verbal quotations from the interviews translated from the Spanish original by Uta Berghöfer and Ricardo Rozzi.

Quotation 1

A woman from the Yaghan Community (2004)

You have to know this: because .... My mum, she knew which tree she had to take the bark off for making canoes. We had no idea. And then, when you get more and more interested in the topic, you start learning and asking more. With Marina [name changed] from the Omora Foundation, it was with her that we went into the field. At first we didn't pay any attention to the branches, the trees, the trunks, but there we learnt a lot of things. (...) And with my mum, we normally accompanied her to look for things, for, for the bark of the tree. (...) But we took the bark off any tree, even though it is not just from any old tree that you can take the bark. (...) I don't know why our parents did not teach us or want us to learn the Yaghan language. Surely because they were very much discriminated against because of their... they were discriminated against for how they talked, and therefore they decided to forget about everything. I like to think about it in this way instead of thinking that it was a personal choice like "Ah, I don't want to speak my language". I imagine that it has to be for this reason, because we already went to school, we never knew that...I never heard my mum talking to other people in Yaghan.

Quotation 2

A Yaghan father and his daughter (2004)

Question: “'Which places have you been to in the region?

Father: "In this region? Umm, I have been everywhere, my dear."

Question: "Even to the interior of the Island?"

Father: "Yes, to the middle of the Island, yes.., I have been everywhere. I have seen the whole interior of the Island."

Daughter: "I do not know a lot of the area. I know from Eugenia to Navarino [the range of the only road along the North coast] and ...Button and Wulaia [historical place on the West coast].

Quotation 3

A Yaghan fisherman, who spent his childhood at the boarding school (2005)

"How did you learn about birds for example?"

"From elder people, from the natives, while at sea, (...) and later on, I finished learning about them when I went to stay with my father, on the beach." 
Quotation 4

A woman from an old settler family, born in the region (2004)

"I got to know all the places when I was a child. I know for example all the places where the biggest calafates [Berberis buxifolia] grow, where you can find more wild strawberries, where the dihueñes [Cyttaria darwinii] are, and where they grow more yellow than in other places."

\section{Quotation 5}

A resident, who has been living in the Region for eight years and working in the tourism sector (2004)

"I like reading very much, and in particular I like reading about the places where I live or that I know, especially everything of this kind. Sometimes it doesn't matter if it's a novel or a story, but it has to do with... it has to describe the landscape that I know or where I have been"

Quotation 6

A woman whose husband works for the navy (2004)

"How do you know about the Caiquén [Chloëphaga picta picta]?"

"Because I know it from television, from a magazine, from a brochure when I was in Ushuaia, there was also the Caiquén in it. (...) [I know about animals] from television, from the Discovery Channel. The only thing I ever watch is about animals."

\section{Quotation 7}

A settler from a Navy family, who came to the region at the age of five (2004)

"Before, when I owned a mini-market, I spent the whole day in the store, ...the store, ...the store. I had zero contact with nature. When I went outside, I walked a bit but did nothing else. Now I have another vision. It's important. Now that I'm more into tourism I can appreciate more."

Quotation 8

A Yaghan woman recounts her childhood (2004)

I know all the places, because I used to accompany my father a lot, to all those places they went for sheep-shearing. And we always went with him. (...) About five years, working with sheep and cattle. (...) I was also a fisher-woman and went fishing. I used to go out in search of centolla. I always went with my dad.. we went off fishing. (...) In the countryside we always raised animals.. sheep, because at that time the majority of people used to raise sheep.

Quotation 9

A woman from an old settler family (2004)

I always liked the guajatana [Nycticorax nycticorax obscurus]. Because it is a lonely bird, you never see it with a partner, it is always on its own. And at night it squawks. And I always used to say "Hey, you are lonelier than a guajatana' (...) A bird that is always around. I like it. (...) It is an odd bird to look at, it has charisma some how, I don't know. Huairavo is the scientific name. I know it as the Guajatana, by its Yaghan name, as my dad used to call it.

Quotation 10

A wife of a navy member (2004)

"I like the avocado tree, because in the fifth region, everyone in my family grows avocados, I like the avocado tree, and I also like avocadoes." 
A resident from the Yaghan community (2005)

I like the horse. (...) What happens is that if you grew up in the country, suddenly the horse becomes man's best friend in the country. I think that in the countryside and not just in the countryside it should be like that. Even though in the city the horse is not a means of transportation, not at all. The horse was made for man. And man at the same time was made for cohabiting with the horse.

Quotation 12

A recent settler (2004)

"I like the sea, definitely. Yes, any landscape that is related to the sea. I have always been very close to the sea. I like it very much."

Quotation 13

A woman from a settler family (2004)

"I have something of a close connection with nature. I love it. If I could, I would have a farm with all the things that go with it. I would love to live like that. In a city, no, no I wouldn't like that. I'm more from the country."

Quotation 14

A woman living temporarily in the region (2004)

"I am water and vegetation. I love to be close to a river, a lake...the sea. And if you add vegetation to that, I'm very happy."

Quotation 15

A navy soldier (2005)

"My grandmother had a farm to the south of Valdivia and during vacations they sent us, all the cousins, there. We used to get up early to milk the cows, to see the animals, to take the dogs out, to go and look for the chickens, to go into the city to fetch the water (...). So, I have plenty of contact with nature."

Quotation 16

A navy soldier (2005)

"If I had to make a choice, then I really like the eighth region. On the one hand I' $m$ from there and on the other hand you have... it is a big city [Concepción] and all, but there are still lots of places where you can go out and see a lot of vegetation, landscapes, and nice places."

Quotation 17

A woman living in the region for more than 40 years (2004)

"I love nature. Well, I'm actually from the countryside, but the countryside in the central zone of Chile"

Quotation 18

A fisherman from a settler family born in the region (2006)

"I just live my life according to the sea."

Quotation 19

A woman temporarily living in the region (2005) 
In my personal experience, when I'm in the North [of Chile], two things happen to me: one is that I do not go out a lot, except to see my family, and to go to the countryside, but as it always was. I never go out with that vision of a person coming from somewhere else "Oh how nice!" Like people do coming here. In my case it is because it is something that I have always known, maybe it doesn't have the same enchantment that it had the first time. But it happens to me when I am here: the landscape is different, it seems to be much more impressive, more grandiose, I don't know: the mountains are very high, everything is green, and that's what I like.

Quotation 20

A fisherman from the Yaghan community (2005)

What is valuable here, on Navarino Island, or what attracts my attention.. nothing really, that is because I'm from here.... maybe if I went somewhere else and you asked me about it, then I would probably say 'this or that stands out,' but here on this Island I can't.

And in the surrounding area?

Well, I know everything. For tourists from outside, there are many things that they would like, many places.

Quotation 21

A fisherman from a settler family born in the region (2006)

"I don't know if it [Centolla: King crab] is overexploited. I think the animal is very intelligent. Who knows, maybe it is more intelligent than we are. If it sees all the traps, a lot of traps, it hides itself. I think it could be like that. Really."

Quotation 22

A recent resident (2004)

Do you see any threats to nature in this region?

Yes, definitively. Yes. Look, there are problems with the forest and we have problems with the Centolla [King crab] (...) I always make predictions and I say: from now on in twenty years, what will have come of Williams? There will be no centolla, first of all. And they will have to do something in order to protect the forest, and birds and everything that's in the forest.

Because if they continue to allow the trees to be felled, they will have to create places for its preservation, which will not be touched. If not, there won't be any left in twenty years time.

Quotation 23

A wife of a navy soldier (2004)

"We have to protect it, the little bit of nature that is left. It is we who have destroyed nature, and in the long run it is we who will be the criminals on this Earth."

\section{Quotation 24}

A more recent resident working temporarily for the civil service (2005)

"I imagine people living in peace and tranquility, who enjoy this value, which is very rare indeed in the big cities. (...) People who are very proud of being able to recount."

\section{Quotation 25}

A woman who has been resident in Puerto Williams for eight years (2004)

"First, I would protect the forests, because I feel worried thinking that it is us, who is destroying the forest. (...) Because everybody that I talk to, the people that are coming here, the first thing they say is: this is beautiful, the trees, the green.. Everybody is looking for what we are destroying and that is 
terrible."

Quotation 26

A woman who has been resident in Puerto Williams for 18 years (2004)

For me it would be horrible if there was a building, or a five star hotel in the middle of the island. Or a McDonalds on the Cape Horn, for example. I think we have to leave such things alone. Because for me it would be a form of aggression. Absolutely. For the environment and for us. Because we decided to live here for a particular reason. I think it would be really aggressive to install traffic lights or escalators. Or if they erected a completely gray block building. I think it would be terribly violent. I wouldn't like that.

Quotation 27

A resident from an old settler family

How did you learn about the plants, the animals, about nature?

From my dad. He taught me everything that I know today.

He told you?

No, I worked with him. I always accompanied him when he worked.

Quotation 28

A fisherman who came to the region at the age of two (2005)

Is there any plant, animal, or bird that is important for you on this island?

Look, I don't know... Specifically I couldn't tell you, but personally, as if...not that I do not attach some importance to, but ....I don't know, I never touch these topics like: I value this, or I study that...But, no, like you...personally I would like it if this natural environment does not change. In summer, for example, the wild strawberries, the calafates [Berberis buxifolia].

Quotation 29

A fisherman who came to the region at the age of two (2005)

If you could protect any plant, animal, bird or place on Navarino Island, what would you like to protect?

What would I like to protect, if I really could?...I'm so accustomed to, to this, to this environment/these surroundings of, of life, of seeing these animals, of seeing, of seeing the birds...

Quotation 30

A fisherman from a settler family born in the region (2006)

"The sea is something beautiful that maltreats us a lot, that chastises us a lot. But it also gives us benefits."

Quotation 31

A fisherman from the Yaghan community (2005)

"The nicest ones could be the seagulls, because they accompany you. There are some very small seagulls; they look like seagulls, which have a red bill. They are really nice, like the seagull but smaller. When you are fishing they stay by your side."

Quotation 32

A woman who has been living in the region for 2 years but spent her childhood in the Atacama desert (2005) 
The truth is that nature is, well, my contact with nature has been something that one does not understand... the bare desert, the most real desert in the world.

And this is not nature for you?

I don't know, but it is not ... I felt it was like part of... of normal life, if you understand? When I studied nature, that was, when I came across this. The South [of Chile] I always got to know very fast, and even though it was very fast, it was like an encounter, I don't know, with the green, the exuberant, exuberant because, well there it is also exuberant in its

immeasurableness. When we talk about nature, we talk about this, and not about the bareness, the stones, the...

You lived there when you were a child?

Yes, sure, and, for example, when we went to school in the morning, we climbed down a canyon, if you didn't you would've had to have gone on a major detour. But you had to climb a real canyon. Then you passed across a group of guanacos [Lama guanicoe], then you passed a river frozen with ice, after walking another kilometer, you climbed up next to some plantations and then reached the school. And the way back again.... Sometimes you spent the whole day getting to school, because you came across some fruits, or you was kept by the river where you could do some ice skating, or you saw a little animal, or the donkey, or would watch the animals grazing.... A life...sure, I was...but I never thought about my relationship with nature.... the first time that I thought about my relationship with nature, do you understand? Because, sure, you know how to pick a fruit without getting thorns stuck in you, I don't know, just to give an example. (...) That I go to the mountains here, like in a voluntary way, no, if I have to go to the mountains in order to do something, to look for water, to look for something....my relationship is somehow more practical. It is more like a necessity, more like, I don't know if I can call it natural, I don't know. But, well, the fact that I go for a walk, well when I had to cross eight kilometers of desert it was because I was in a village and we lived there and there wasn't any other way other than walking. And you couldn't distinguish anything, but you had to distinguish the colors in order not to walk past the place where you lived, because the houses made of loam are all the same color like the soil. So you can't see the ground but I always saw it very clearly. You go out of the house and you know how to get back, but I would never go out just to experience walking in the naked desert, no! You have to do it and you just go, if you know what I mean? In this sense.

Quotation 33

A fisherman born in the region (2006)

Well, you learn with experience as the years go by. Because, suddenly you see something you don't know, but the elder fishermen you get to know, they will teach you how to distinguish between the species. It is the only way to learn. You do not study this, in fact, if you do not know something you will go and talk over there, in the cove of the fishermen and you say 'Hey listen, I have seen this, and it looked like this' and then they will tell you what it is called. Well, there are lots of species you do not know and they keep on appearing. (...) So, you never finish learning. The sea is endless. There are lots of things in the sea."

Quotation 34

A fisherman from the Yaghan community (2004)

"I have worked ...well, I have worked nearly everywhere. Windhond, Yendegaia, Navarino, Douglas and Lennox, Nueva, Picton, everywhere... I really like everything here. Everything, everything... because I think that in other places I could not be...I would not feel comfortable in another place."

Quotation 35

The wife of a n navy soldier (2004)

“Well, I don't know anything about the names. I can only see that there are different forms of green, 
different leaves (...) but more than that, no idea."

Quotation 36

The wife of a navy soldier (2004)

"It's a little, I do not know, because I stay more in the house, I don't go out a lot."

Quotation 37

A woman living temporarily in Puerto Williams (2005)

In the kindergarten they teach the children like this: very formal. Like: yes, you do it right. With my grandmother or my mother they would say to me: 'try this, this is cochayuyo (Durvillaea antarctica) [edible algae].' But now it is more formal, more intellectual, like a concept. More theoretical rather than doing it yourself.

Quotation 38

A woman from the Yaghan community (2004)

Well, now, it is becoming a bit more complicated because the national forest service (CONAF) asks you to have a permit, or they tell you where you are allowed to take the bark from. These things seem horrible to me. But we do not follow those rules, because we are not destroying the trees. Nor do we take the bark from all of the trees. And because anyway, in the past there has never been an ecological disaster because of the Yaghans. It is not our fault. For example, the relationships, the relationship that the Yaghans had with nature was very different, because... for me that would have been perfect, well, I would have loved to have been there (....) For me, the birds, in the past the birds were once human beings, a Yaghan legend says. For me they are important, because they are like persons.

Quotation 39

A woman from the Yaghan community (2004)

I would like it to be a normal place, and now I don't see it as too bad, well.... it is not too crowded. But I imagine it as a place surrounded by culture, and aware of what we have. I think that here, people do not make use of all the things that we have. All the products from the sea, all the products that we could use, I don't know. To elaborate, but to concentrate on this same place. Not to focus outwards, or for other people to come here: really, that is what I fear, the invasion. I would love it if the same people that live here could.. work with what is here and live their whole life here, as natural as possible. And for us, as the Yaghan community, I don't know how many Yaghan, but at least those who are concerned about the preservation of our culture. I think that we could do much more. And I see a lot of work to be done there..., I see the need for bringing back and resurrecting the Yaghan world a little bit. Resurrecting it through the rejuvenation of our language, and above all, through handicrafts, and through being able to say that we are Yaghans. Because we are different and yes, we know and value what is here. I think this is what I see below the surface. From those of us who are working. Yes, I believe that we could recount our history. I think it should be us who are recounting and and showing our history.

Quotation 40

A woman from the Yaghan community (2004)

What do you like about life on Navarino Island?

The nonurbanization. I think that is what I like about the island; although now the city is growing day by day and there are more cars, and more telephones, and more... but what I like about the island is that... well, it is an island. You see, an island is like moving away a bit from 
the global world. That is what I like, and I wish it could be even more like that. Less

inhabited, but anyway.

Quotation 41

A farmer from the Yaghan community (2005)

"For me it is important: I look after the land, I make my living from it. I take care of it. I do not abuse it and I do not overexploit it in any way."

Quotation 42

A discussion between two brothers who have been residents of the island for 8 years (2004)

First brother: When we walk in the mountains, we can see beaver dams.

Second brother: But the beaver dam is not natural.

First brother: Is not natural?

Second brother: Because it was built by the beavers.

First brother: But, well, it is also an animal. The only difference is that it has been introduced.

Second brother: I think that if you say natural, I think that natural is what has been made by

nature, without intervention. Because if it has been made by the beaver...

First brother: Isn't the beaver a part of nature?

Second brother: I think that the beaver...

First brother: It is not from here.

Second brother: It is not from here, humans brought the beaver with them and as they did it, so then there is the human component involved in it.

Quotation 43

A man from a settler family (2004)

"I like the beaver because he came to settle down and he is from here, he is from [Puerto] Williams. He is like we are. We came to settle down and now they will not remove take us out any more."

Quotation 44

A man from a settler family (2004)

The animals I like? Despite the fact that nobody likes him, the one I like most is the beaver. It is an impressive animal. Many people don't like beavers for the ecological damage they have caused here. But for what I have seen: with a friend of mine we destructed some of the beaver dams, took of the trunks and everything. That happened at six o' clock in the afternoon, and already the next day at eight in the morning they had their dam reconstructed. The work they are doing, really great. Well, it would be a pity, but from the environmental perspective it has to be done, they have to be eliminated. But the work they are doing is really admirable, yes.

Quotation 45

A fisherman from a settler family born in the region

Well, I think that the area should be divided, into sectors, and it should be said: This sector, these waters here will not be touched over the next two or three years. So, we will work from here to there. And if the resource is scarce, I think that the industries will have to raise the funds in order to pay more for the small amount that comes out. Do you understand? So, if you let the area recover for three years there and then after three years you go back to work there then that will be more sustainable for all those who work there. (...) It would be a good idea to divide the area. 


\section{APPENDIX 3. INTERVIEW QUESTIONS}

1. If you think of animals/birds/plants, which are the first that come to your mind?

2. Which animals/birds/plants do you know in the region?

3. How did you learn about plants, animals, or nature?

4. Is there any plant or animal that is important for you on Navarino Island? Why?

5. If you remember your childhood, how did you spend it?

6. What is most valuable for you on Navarino Island?

7. To which places have you been here in the region?

8. What did you do when you went to those places?

9. Do you work in the forest, in the countryside, or at sea? What kind of work? Where do you work?

10. Do you see any threats to nature in this region?

11. Which place on the Island or in the region do you like the most?

12. What do you do when you go out in your free time?

13. If you could protect any plant, animal, or place on Navarino Island, what would you like to protect?

14. How do you imagine Navarino Island in 10 years time?

15. What are the places or cities in which you have lived up to now? 
Appendix 4. Example word-by-word analysis

\section{Please click here to download file 'appendix4.pdf'.}

